\title{
Role of the university librarian: a review
}

Jayasuriya, Sumana ${ }^{1}$

\begin{abstract}
The paper tries to analyse the role of the university librarian using a sociological definition for the role. Considers the University as a social institution and how the role of the librarian evolved to meet the changes taking place in the Universities. Elaborates management and functional competencies, qualities, technological and human relations skills they need to develop in order to cope with the modern Information environment.
\end{abstract}

Key words: librarians, Academic Libraries, University Libraries

\section{Introduction}

Demand for information is on the increase across the globe but the demand for better access to information is more marked in higher educational institutions as subjects taught and research becomes more specialized and interdisciplinary. It is also a fact that range of information sought by researchers are growing continuously and academic libraries are faced with the problem of supplying timely and adequate information held by libraries not only in printed form but also in electronic form including on-line data. How do academic librarians cope up with the growing demand? During the last few decades the landscape of the information environment has changed dramatically due to the use of technology on one hand and ease of access to information on the other. Academic librarians have grown more accustomed to the rapid pace of change in their libraries. In such an environment has the role of the academic librarians undergone changes? Have the goals, expectations, functions, changed? Have skills, been affected by these changes? What should be the role of an information professional in an academic setting?

\footnotetext{
${ }^{1}$ Former Librarian, University of Colombo, Sri Lanka. Email: sumanaj@lib.cmb.ac.lk
} 
Journal of the University Librarians Association, Sri Lanka, Vol. 16, Issue 2, July 2012

Encyclopaedia Britannica defines the role as follows:

Role, in sociology, the behaviour expected of an individual who occupies a given social position or status. .... An individual may have a unique style, but this is exhibited within the boundaries of the expected behaviour. ..... Role expectations include both actions and qualities.

The International Encyclopedia of the Social Sciences describes "role" as representing "the behavior expected of the occupant of a given position or status with emphasis on expectations (beliefs and cognitions) and enactment (conduct)."

Blackwell Dictionary of Twentieth Century Social Thought defines Role as "Denoting sequences of behavior emitted by individuals occupying, or seeking to occupy, a particular position in a social situation ..." (p. 564).

According to these analogies, to perform in a particular role an individual must be receptive to the expectations of the role for which he or she is responsible, and this analogy can be used to understand how academic librarians cope with and adapt to change. If librarians are to adjust within the university community, they must adapt, reinforce, and adjust their role in response to library staff or information users. Once individuals understand their roles, they can usually cope with and respond appropriately to recurrent situations. Through this continuous process of self-examination and selfdefinition, individuals understand and perform a role by incorporating appropriate behavioral changes. It can be assumed that, role encompasses an interactive system of behavior, values, skills, and functions all performed within the context of providing academic library and information services. 
Journal of the University Librarians Association, Sri Lanka, Vol. 16, Issue 2, July 2012

\section{The University as a Social Institution}

With the expansion of higher education, the universities are pressurized to educate more students and undertake more research at a lower unit cost. They are also expected to be self financing institutes getting less and less from the state. In order to meet these expectations, universities are offering number of courses on campus as well as outside the campuses and also in countries outside their own. New subject disciplines have emerged with old boundaries disappearing; demands and expectations of the academic community has undergone changes; new subjects for study and research have proliferated; mass higher education and change in methods of teaching and learning have taken place; old methods have been replaced by student centred learning; project work, group discovery and individual reading programmes, subject options, modular courses have become essential components of the courses of study. To cope with the demands the users will need to acquire skills that will allow them to continue to acquire knowledge, and academic librarians have to find ways and means to cater to mature students.

In this set up, libraries are faced with the problem of being selective in what they acquire in the wake of expanding range of literature and information being published, and available via internet. Another problem associated with this is the provision of infrastructure and the tools to deliver a satisfactory service.

One of the most important activities of any library is to recognize the most powerful and influential constituents. In a university, the three most important segments are the administrators; faculty and the students. Academic staff is usually seasoned scholars who either received formal training in information gathering skills or have acquired the skills through years of publishing and research. Administrators are responsible for decisions on funding and other policy decisions. This is not to say that students do not comprise an important segment, as the services are delivered focusing them. The internet has changed the way the scholars communicate and the technologies associated with are 
Journal of the University Librarians Association, Sri Lanka, Vol. 16, Issue 2, July 2012

evolving hence, internet has become the focus of user education workshops. Change in mind set of undergraduates who have grown up with technology and a strong demand for quick answers need to be understood by the librarians. In this backdrop, libraries are considered as the best link between the new and evolving technologies and the campus community.

The Library Client Charter 2000 identifies the university library as the "key facilitator of information access for research, student-centred learning and information literacy' (McSwiney and Parnell, 2003). Due to the expansion of information resources, instruction in the use of these resources has become very important especially in universities with a large under graduate population. With the growing number of databases, and online journals, developing on-line search strategies to make a successful search has become essential. There is not only the problem of finding the relevant source material from among the vast number available; there is also the problem of effectively using the source material. The users should acquire the skills necessary to find and use the material. This entails that the users be familiar with the availability of web search engines and also to use them. Here the librarians are expected to act as intermediaries in instructing the students on the use of web search engines, and other necessary software. As a result of these changes, the focus of the information profession has been moving back to the user as they are expected to be translators, guides, and teachers for the user. They spend more time with the user which affords them an opportunity to discover new information or new information tools.

Another aspect of this scenario is the existence of a vast difference between traditional on-campus and online teaching environments. Online teaching environment provides opportunities for access to courses and students, but questions relating to connectivity, formatting, use of software packages, writing skills crop up all the time. Nature of communication between students and librarians are always in written form which gives both parties to think about and understand the problem/ response carefully. This is 
Journal of the University Librarians Association, Sri Lanka, Vol. 16, Issue 2, July 2012

different from conducting face-to-face reference interviews conducted in a normal library setting. Even the academic staff teaching online for the first time may appreciate support from a librarian who is experienced in the online environment. "One of the most positive aspects for librarians working in an online environment, is that there exists the opportunity to make a real difference to the information literacy of students. In order to take full advantage of this opportunity however, librarians must be prepared to expand their traditional reference roles to give advice and coaching on all aspects of the assignment and research process. The skills gained and the lessons leant are carried back into the traditional environment as librarians gain a better understanding of students needs and course content, cultures and requirements, and thus can provide a better service to all students." (Perrone, 2000)

Francis Miksa (1992) as described by Rice-Lovely and Racine posited two paradigms which considered library as a social institution. Traditionally the library was viewed as storehouses of knowledge with librarian serving as the keeper of knowledge, and the librarian's role was to organize, provide access, maintain, and ease of access to the reader to gain knowledge. Reading was perceived as an inward-directed activity designed to improve the inner person. The second paradigm focuses on the process of information movement which contributes to the system of human communication. According to Miksa, the paradigm shift had taken place due to changes in the information environment; users seeking knowledge earlier now seek information; librarian's role changed from being a keeper of books to a network navigator, and provision of raw data changed to provision of information. Now the librarian/information professional interacts with an information environment represented through Internet which is complex, multidimensional and dynamic. In order to fit into this new paradigm, "First, librarians must distinguish and interpret cues from a system (social and technical) that is in constant flux. Second, they must recognize that all of these most fundamental changes necessarily affect the functions they perform, the skills, abilities they must acquire, and often even the personal qualities demanded of them."(Rice-Lively \& Racine,1997). 
Journal of the University Librarians Association, Sri Lanka, Vol. 16, Issue 2, July 2012

Further Miksa says that the modern library has moved from private to a public institution where the information professional is the key to the process of sense making and value adding that enables users/clients to create their own information spaces.

The library as a social institution and the librarian when taken as separate entities, responds to hints or ideas from the other in performing a particular role. For this reason, although the role of the library is separate from that of the librarian, the roles are intimately intertwined and must be considered together.

\section{Use of Technology}

With the increase use of technology, university libraries have grown more accustomed to the rapid pace of change. The question arises whether during this period of rapid change, the functions, skills, and expectations of academic librarians have been affected by the use of these new technologies. Whether their role has changed significantly over the years to meet the demands presented by use of technology? Taking into account the shift in information-seeking behavior, Miksa's second paradigm for libraries focusing on the process of information movement which contributes to the system of human communication has deeply influenced the LIS field. It has contributed not only the word "information" to the name of the field, but supplying an entirely new set of terms by which library and information science practitioners might characterize their activities.

Use of technology has removed many inherent obstacles to the communication of knowledge to academic world via e-mail, e bulletin boards, list serves. It also supports invisible college of scholars. Is internet an alternative to university library? Information technology must be used intelligently to improve integration with academic community, dissemination of information more effectively, improve services for least additional cost realizing that technology has its own problems. Smethurst (1999) opines that as following: 
Journal of the University Librarians Association, Sri Lanka, Vol. 16, Issue 2, July 2012

If the library is to be at the heart of the university then we must change our practices, and our user's expectations. We must offer new leadership to the academic community. Those librarians who are unwilling or unable to provide visionary and practical leadership for the development of new information service strategies will inevitably find that the library becomes marginalized. (p. 41).

Academic librarians need to define students' needs and the concept of integrated development has to be accepted by the teachers and librarians. Technology should be used to improve access, and to create course materials. Librarians must work towards removing barriers within and between library and other services. Continuing education of library staff and user alike on all aspects of information provision and training in the skills that the changing technology requires is essential. Unlike the use of printed material which is logically structured, using a virtual library and on-line access to unlimited information sources at a screen poses several problems for the user. They need continuous training though the ultimate form of access should be self service. Providing online help desks needs competent officers who can take users though the process of screen by screen. Assisting the user in an electronic environment is a collaborative endeavour; between the librarian and the user who both contribute to the search.

Diverse groups of members in a university community have different needs and wants. Simply transferring print publication to websites won't work and are not desired by everyone, and a gradual transition may be required. Members expect more than mass distribution of the same information as they are looking for information geared to their particular interest and needs. The cost of implementing new technology delivery channels is also expensive. There are actual costs and the hidden costs in terms of staff time, the challenges in changing how we think about and deliver information, and continually evaluating the effect. 
Journal of the University Librarians Association, Sri Lanka, Vol. 16, Issue 2, July 2012

Librarians can and should expect more change at an accelerated rate. Clients and customers in a technology based society want and demand that librarians use and understand technology and that they use it to provide the services. The teaching component which was always present in library profession, which started with explaining how to use our libraries to locate books, and led to training on how to use on-line databases, will continue to expand as the gap grown between those who have access to information and those who need access to information - the digital divide.

As a key point of contact in gathering information, librarians will require skills in training adults and young people alike and librarians themselves have to continue to upgrade their skills in these areas and keep on top of technology, particularly those who work on the front line. They must continue to build their skill sets. Lack of resources, constant change, the need for flexibility and effective communication and marketing will continue to define what librarians do and how they do it.

\section{Evolution of the Role}

Traditionally, meaning of the term "Librarian" was associated with someone who finds information for others. A study of library literature reflect on the qualities and functions of academic librarianship and illustrates some of the expectations, beliefs and behaviours of academic librarians which gives a glimpse of the evolution of the role of an academic librarian. Originally, the librarians' primary function was of a custodian where they were expected to protect collections and exercise control over their use. Gradually the librarians were expected to develop and maintain separate collections for undergraduates, and provide special library services. However, Melvil Dewey (1876) called librarians to a mission beyond keeping and preserving books and described following:

It is not enough that the books are cared for properly, are well arranged, are never lost. It is not enough if the librarian can readily produce any books asked for. It is not enough 
Journal of the University Librarians Association, Sri Lanka, Vol. 16, Issue 2, July 2012

that he can, when asked, give advice as to the best books in his collection on any given subject.... He must put every facility in the way of the readers, so that they shall be led on from good to better. He must teach them how, after studying their own wants, they may themselves select their reading wisely. (p. 5).

Dewey's emphasis was the organization of collections for maximum use, and the librarians to be educators so that users select their reading wisely a philosophy advocated by S. R. Ranganathan in his Five Laws of Library Science. By 1900 the universities in the West, expected librarians to support the students in their studies by instructing them on how to use the library, and to some extent, how to conduct research. Furthermore, librarians were invited to give lectures in bibliographic instruction.

When collections became large and libraries became functionally organized, the role of the librarian turned inwards and they became more closely associated with the functions such as cataloguing, classification, or reader services. With the increased complexity and specialization of knowledge with too many publications coming to the market the librarians had to filter the flow of new publications as it became too much for faculty staff to deal with. Librarians provided assistance to select material and their role shifted from being helpers in finding information to shapers of contents and services of the library.

By mid 1960s, advances in networking technologies that permitted computers to connect users with data at remote sites influenced academic library routines and services and eventually the role of the librarian. Developments in communication technologies and the development of MARC format which facilitated transfer of information changed the ways in which users were served in the university libraries. Harlow (1971) as cited by Rice-Lively \& Racine (1997) described this new development as:

Since information could be located anywhere, the focus shifted from the place to the user. Second, the availability of enhanced access to a much broader spectrum of information resources placed increased emphasis on librarians' skills as subject 
Journal of the University Librarians Association, Sri Lanka, Vol. 16, Issue 2, July 2012

specialists, as teachers, and as interpreters of the information needs of their library clientele.

This expanding role led some-but certainly not all-academic librarians in the 1960s and 1970 s to seek a more prominent place in the university community by achieving faculty status. In 1971, the Association of College and Research Libraries adopted a document with the hope of favorably influencing the number of colleges and universities granting faculty status to librarians. The controversy of faculty status for academic librarians continues to inspire discussions between both tenured and non-tenured librarians.

\section{Change in Functions}

The role of the academic librarian became more closely associated with or defined by the functions of the employing units, which were (and still are, to a certain extent) functionally organized. Literature of 1980s, highlight the changes in the role of the librarian with the increased availability of and improved access to computing and information technology. As a result, the functions of the librarian changed dramatically, so much so that librarians started questioning whether the title "Librarian" is adequate to describe the position they held. During this period alternative titles have been suggested which accurately reflect the responsibilities of the librarians. 'Academic Reference Librarian' who provided information or assistance in finding information (Cardina \& Wicks, 2004); 'Internet Reference Service librarian' to coordinate use of internet as a reference tool in the library and the campus; 'Digital librarian' to facilitate access to information just-in-time to the critical wants of end users and additionally to facilitate electronic publishing (Sreenivasalu, 2000); 'Academic Liaison librarian' to provide undergraduate students with training and support in a range of study information and writing skills (East, 2001); and 'Faculty Outreach librarian' to educate faculty on the growing role of information technology in research and teaching, and to enhance their support for new electronic resources (Stebelman et al., 1999). 
Journal of the University Librarians Association, Sri Lanka, Vol. 16, Issue 2, July 2012

Literature provides a chain of functions for academic librarians: archiving material; acquiring; transforming; and repackaging information; producing secondary information; teaching and coaching; and several others. Increased need for collaboration between the information professional in the academic library and the others associated with information work was emphasized. Academic institutions offer opportunities for collaboration with computing departments, academic departments, and other academic and research institutions, with vendors, governments, and so forth and academic librarians should make use of these opportunities.

East (2007) concluded that in 1990s traditional roles of librarians disappeared and the librarians turned towards Information Literacy as their salvation. According to him, librarians came out as teachers who would guide the students through complex process of information discovery and evaluation, to ensure that students learn appropriate information skills to help them achieve information fluency. With the expansion of transnational programs, the libraries recognized that they had a critical role to play in teaching and learning process of the university community in promoting graduate qualities, and the survey conducted by East revealed that academics interviewed shared this conviction. They also thought that physical presence of a librarian, and face-to-face contact and mixed mode of delivery was advantageous, to solely on-line IL programs. The study also found that 'librarians can contribute to teaching programs at faculty level, and that the roles of the library and librarian need to be even more firmly embedded in the teaching and learning of the faculties.' Information literacy is therefore a shared responsibility of academics and librarians. Use of e-resources by students who lack academic training and discernment in evaluating the material they access is a concern for librarians.

Rible (1999) who became the campus webmaster at Southern Oregan university opines that though librarians have always been great at finding, organizing, and disseminating information but as a profession they lack the training to be developers of the systems 
Journal of the University Librarians Association, Sri Lanka, Vol. 16, Issue 2, July 2012

that manage the information, therefore rely increasingly on outside technical expertise. He further says that there is a great deal of potential for computing center and libraries to merge services, philosophies, and personnel, and that it'll strengthen the roles of both parties. Librarians can add value to computer by creating new services and improving all traditional existing services.

Cardina \& Wicks (2004) who studied the changing role of academic reference librarians over a period of 10 years (1991-2001) found that the roles of academic libraries have reflected the change, and automation systems was the driving force behind these changes. The study also revealed that their roles have changed over the 10 year period due to the change in resources and demand, though 'Core tasks' identified as face-toface reference work, print collection development, bibliographic instruction, and attending meetings still remained at the core. Emphasis was on patron and not on technology. The main function was the responsibility of meeting the information needs of the faculty with the use of electronic lists, e-mail accounts, individual consultations, in addition to work shops, campus newsletters, library guides.

\section{Qualities Required of Information Professionals}

Taking the paradigms posited by Miksa, Rice-Lovely \& Racine carried out a survey of academic library professionals, LIS educators, and university students on the hypothesis that Information Professionals are required to exist in both paradigms at the same time. Study venue was a university where technology was used for a long time, and the role defined as a complex concept which should be viewed holistically and each individual functioning in a part of complex, dynamic system where the system components comprised of librarian/client, interactor/user, institution with its many facets, and information resources.

The study revealed that some respondents agreed that the role itself has not changed, since they continue to do the same fundamental activities i.e. determining information 
Journal of the University Librarians Association, Sri Lanka, Vol. 16, Issue 2, July 2012

needs of users and linking the users with resource that will meet those needs, but they use different tools and techniques to access resources. There are no generic roles for either information professionals or users as they possess different levels of expertise, skills, and knowledge. Added to it are cultural and language differences. Users approach libraries with complex set of expectations. The respondents also expressed their views on qualities, new skills and functions expected of librarians. Most important were the human relation qualities which the authors summarized as follows:

Be good communicators-interpreters and listeners-who are intuitive and sensitive enough to perceive nuances (cues) from clients in order to ascertain specific information needs; Use good judgment to determine what kind of information and how much information each client needs, even, as one study participant phrased it, to anticipate these needs Either serve as or construct a "bridge" linking the information and the user. (p. 7).

It is apparent that there is an increased need for collaboration within the profession, across disciplinary and professional boundaries, and within the information industry. IT can help in this endeavour via e-mail, chat, listservs, electronic conferencing, collaboration with computing and data processing departments, faculties.

While the human relation qualities is emphasized on one side, Rehman (2006) asserts that information professionals today need to be more businesslike, cultivating partnerships with business colleagues and IT professionals; capitalizing in innovation for growth and expansion, adding value to information through filtering, synthesizing, messaging, and packaging; and using business metrics for proving value and worth. He further states that the professionals need a new set of competencies to succeed in the profession. According to him the librarians need to develop a corporate mindset, ability to deal with vendors, outsourcing capabilities and competitive intelligence. They are also to acquire management competencies such as strategic planning and decision making, marketing, financial strategies and budgeting, and benchmarking and evaluation. They 
Journal of the University Librarians Association, Sri Lanka, Vol. 16, Issue 2, July 2012

also need to enhance the services by empowering users with customer focus and information literacy.

\section{Skills Needed by Information Professionals}

The networked environment required new skills for the information professional as there has been a gradual shift from print to electronic information sources which keep on accumulating and expanding at an exponential rate. A shift from face to face to reference interviews to e-mail, web based instructions, in-depth consultation, on-line teaching tools are some of the changes which required information professionals to acquire a new set of skills. These skills could be categorized as technical, cognitive, and behavioral with a commitment to life-long learning to adapt to the changing nature of environment, selfdirected and self motivated to develop new skills to make use of the new technology and resources, becoming more flexible and creative in their information seeking habits. Cardina \& Wicks (2004) emphasizes skills in product management: a new skill of designing, developing and making new online services using indexing skills, subject expertise and technical know-how. Stebelman, S et al. (1999) describes a position of Faculty Outreach Librarian created by the George Washington University in order to fulfill the need to educate the faculty on the growing role of information technology in research and teaching, and to enhance their support for new electronic resources. He further elaborated other skills such as leadership skills; entrepreneurship, instructional skills to provide workshops and IT demonstrations; comfort communicating with, and approaching faculty; a willingness to learn and implement different methods of marketing the library's services to faculty and administrators; excellent writing skills for any newsletters and fliers that are developed; excellent analytical skills to assess what is and is not working and to prepare reports for library administrators; a willingness to be proactive, to seek out users in their offices, parties, and departmental meetings; the ability to work independently, given that many projects will either originate with, or be assigned to the Faculty Outreach Librarian. 
Journal of the University Librarians Association, Sri Lanka, Vol. 16, Issue 2, July 2012

East (2007) citing IMLS Task Force on Future of Librarians in the Workforce - University Libraries, 2006, states that as following:

Future librarians will increasingly need to take their skills to the clients that need assistance. That model, sometimes referred to as 'place as library' could be virtual (chat/web conferencing) or in person in remote site classrooms or offices, but the organizational model will change to accommodate the 'travelling staff model'.

\section{Conclusion}

From the very inception of libraries, it has been the role of the librarian to organize and provide access to the collection, to maintain the facilities that house those collections, and to ease access for the reader to gain knowledge. Although their duties changed, the traditional goals of librarianship, as articulated by Dewey prevailed: serving the user, bridging information and user, and serving as a filter interposed between the user and the information. Ranganathan glimpsed the future role of academic librarians as information professionals, a role in which librarians function as filters for the user against the torrent of information disseminated by means other than the printed book. In theory, the professional calling to satisfy the information needs of users remains strong and provides a foundation for this transformation.

Smethurst (1999) see the modern university library as thus:

The university Library must of course be a centre for information; it must also be a centre for culture, for entertainment, for relaxation, for intellectual pleasure, and for making and meeting friends. Above all it should be a centre that merges new and old technologies to provide a gateway offering the widest access to knowledge, no matter how it is packaged.

He says further that librarians must achieve right mix between collection development and on-line provision, between holding and on-demand document supply, taking into account both costs an user needs. The Librarian is a key player in the decision making process because he manages the vital areas of information provision, access to 
Journal of the University Librarians Association, Sri Lanka, Vol. 16, Issue 2, July 2012

knowledge and the infrastructure needed to support research and teaching. To achieve this goal the library needs persons from educationists, public relations, computer learning, subject specialists, etc.

Today the library needs promotion. Users must consider the university library as a place you want to go and place to be. Library should be seen as a part of the university's central mission to educate and promote research. Librarians should promote courses, workshops, conference and individual training sessions on all aspect of the service and its key components. Promoting debates on the impact of technology on education.

Perhaps the role of the information professional has not changed although too many in the profession, it feels different from using print resources. Performing the traditional function as a bridge between the user and the information and intervening in the user's sense making process now occurs in the less static and more fluid world of electronic information. The role of information professionals, demand a composite of activities and skills. First, information professionals fulfill responsibilities by participating in and encouraging collaboration within and outside of the library and even the academic institution. Second, information professionals draw on the human relations skills of communication, intuition, interpretation, and translation to assist the user in the electronic environment. Third, individuals functioning in this role must adjust to an environment where the location and even the existence of important information resources can change from day to day, where librarians have to seek new and relevant information for the users. Information professionals are challenged to evaluate, analyze, and filter the torrent of information flowing from networked resources. Information professionals can face these changes, if they observe the fundamental values of librarianship, namely, service and provision of access to information for the user.

Has the role of the librarian changed with the introduction of electronic information? One idea is that the role itself has not changed as librarians continue to do the same 
Journal of the University Librarians Association, Sri Lanka, Vol. 16, Issue 2, July 2012

fundamental things: determining information needs of the users and linking the users with resources that will meet those needs. Users and librarians both use different tools and different techniques to access information. In doing these, they have acquired new skills, and competencies. Another idea is that the roles are evolving as a result of the effects of electronic information. They are expected perform tasks such as creating WWW pages for the library and for the users, building and maintaining CD-ROM networks, providing instruction in using internet and software tools to mine information, searching the WWW for information sites of value to users. Where are we then? Comment of Paul Hoffert provides an answer:

Mr. Hoffert (Paul Hoffert, the author of The Bagel Effect) commented that he saw two winners among the groups at the table as far as electronic information went. The first group are writers, who will begin to bypass the publishers and booksellers, taking their works directly to the consumer. The second group is librarians who will strengthen their roles by organizing and validating the flood of information, becoming the conduit for users to gather and analyze the information they receive. (Whitmell, 1999).

\section{References}

Blackwell Dictionary of Twentieth-century (1993). Oxford, Blackwell.

Cardina, Christen and Donald Wicks The changing roles of Academic Reference Librarians over a ten year period. Reference \& User Services Quarterly, 44 (2) 1333-142.

Day, Pam. A. and Armstrong, Kimberly. L. (1996). Librarians, faculty, and the Internet: developing a new information partnership Internet Librarian. Computers in Libraries, May, 56-58.

Dewey, Melvyl. M. (1876). The Profession. American Library Journal, 1, 5-6.

East, J.W.(2007). The future role of the academic liaison librarian: A literature review, Unpublished. Retrieved from http://hdl.handle.net/10760/10561

Sills, D. R. (1968). International Encyclopedia of Social Sciences. New York: Macmillan, p. 546.

McSwiney, Carolyn and Stephen, Parnell. (2003). Transnational expansion and the role of 
Journal of the University Librarians Association, Sri Lanka, Vol. 16, Issue 2, July 2012

the university library: a study of academics and librarians in an Australian university. The new Review of Libraries and Lifelong Learning. 63-75.

Majumdar, Apurba. J. and Sharmila, Bose. Impact of internet on LIS education \& role of future librarian

Perrone, V. (2000).The changing role of librarians and the online learning environment, In Distance Education: An Open Question? Adelaide: Australia,11-13. Retrieved from http://hdl.handle.net/10760/5016 e-prints.rclis.org/ bitstream/ 10760/ $5016 / 1)$ perrone.pdf

Rehman, Sajjad., Khoo, D. Singh \& A.S.Chaudhry (Eds.). (2006). Proceedings of the AsiaPacific Conference on Library and Information Education \& Practice (A-LIEP). Singapore: Nanyang Technological University. p.27-33.

Rible, Jim. (1999). The librarian as campus webmaster: careers merging? Computers in Libraries. 19 (10), 18-22.

Rice-Lively, Mary, Lynn. and J. Drew, Racine. (1997). The role of academic librarians in the era of information technology. Journal of Academic Librarianship. 23 (1), 31-41.

Smethurst, M. Meeting new demands : The role of the library as a centre for education and research, $1999 . \quad 37-45 . \quad$ Retrieved from eprints.relis.org/bitstream/10760/9760/1/psab008.pdf

Sreenivasulu, V. (2000). The role of a digital librarian in the management of digital information systems. The electronic library . 18 (1), 12-20.

Stebelman, Scott, Jack, Siggings, David, Nutty and Caroline, Long. (1999). Improving library relations with the faculty and the university administrators: the role of the Faculty Outreach Librarian. College and Research Libraries. 121-130. 